\title{
THE
}

\section{The Relationship between Import Penetration and Operation of the U.S. Textile and Apparel Industries from 2002 to 2008}

Sheng Lu

University of Rhode Island, shenglu@uri.edu

Kitty Dickerson

Follow this and additional works at: https://digitalcommons.uri.edu/tmd_facpubs

Terms of Use

All rights reserved under copyright.

\section{Citation/Publisher Attribution}

Lu, S., \& Dickerson, K. (2012). The relationship between import penetration and the operation of the U.S. textile and apparel industries from 2002 to 2008. Clothing and Textiles Research Journal, 28(3), 119-133. Available at http://ctr.sagepub.com/content/30/2/119.abstract.

This Article is brought to you for free and open access by the Textiles, Fashion Merchandising and Design at DigitalCommons@URI. It has been accepted for inclusion in Textiles, Fashion Merchandising and Design Faculty Publications by an authorized administrator of DigitalCommons@URI. For more information, please contact digitalcommons-group@uri.edu. 
The Relationship between Import Penetration and Operation of the U.S. Textile and Apparel Industries from 2002 to 2008

\author{
Sheng Lu, University of Rhode Island \\ Kitty Dickerson, University of Missouri
}

\begin{abstract}
The U.S. textile and apparel (T\&A) industries have respectively adopted various restructuring strategies in recent years which fundamentally changed the way the two industries operate and the shifting relationship of each sector with imports. This study empirically tests the relationship between import penetration and the operation of the U.S. T\&A industries based on data at 4-digit North American Industrial Classification System (NAICS) code level from 20022008. Results from the panel data model show that overall the U.S. textile industry formed a weak cooperative relationship with import penetration level in the U.S. market and a neutral relationship was suggested for the U.S. apparel industry with imports. These findings contribute to understanding the global nature of today's U.S. T\&A industries and suggest useful perspectives for the U.S. textile trade policies.
\end{abstract}

Key words: U.S. textile and apparel industries, restructuring, import penetration 
Since 1960s, the United States has quickly become one of the largest importers of textile

3 and apparel (T\&A) in the world (Dickerson, 1999). In 2009, U.S. textile and apparel imports

4 totaled $\$ 17.90$ billion and $\$ 63.10$ billion respectively, which were nearly four times as much as

5 the import volume in 1990 (OTEXA, 2010). Concurrent with the quick increase of imports, the

6 U.S. domestic T\&A industries suffered from steady reduction of output and great loss of

7 employment, especially for those manufacturing-concentrated functions (Abernathy, Volpe, \&

8 Weil, 2006). Understandably, imports were largely blamed for causing the difficult situation of

9 the U.S. T\&A industries (Nordas, 2004). More specifically, the rising import penetration ratio

10 (IPR) — the percentage of domestic apparent consumption supplied by imports (Morgan, 1988, p.

11 13), was often identified as the threatening and disruptive factor to the survival of the U.S.

12 domestic textile and apparel firms (Krueger, 1996).

13 However, one important aspect of the story often overlooked is the dramatic restructuring

14 process that has occurred in the U.S. T\&A industries in response to globalization. For example,

15 after abandoning most of the domestic production capacity in favor of outsourcing, U.S. apparel

16 firms have established solid business relationships with apparel exporting countries, either

17 through cut-and-sew contracts, opening and owning plants, or full package sourcing (Abernathy

18 et al., 2006). Regional trade packs such as the North America Free Trade Agreement (NAFTA)

19 as well as the elimination of the quota system have also enabled the U.S. textile industry to form

20 much closer ties with business partners outside the U.S. borders and to take greater advantage of

21 resources on a global basis (Gereffi,1999).

22 Capturing the relationship between import penetration and the operation of the U.S. T\&A

23 industries in the globalized era is of value both to academia and government policy making. For 
24 academia, this relationship is important to the understanding of the global nature of today's T\&A

25 industries, particularly as to how the adoption of various restructuring strategies fundamentally

26 transformed the way the industry functions in more developed economies. If a non-competing

27 relationship different from the traditional view is suggested by the findings, it may call for 28 rethinking the conclusions of many existing theories built upon old paradigms when

29 globalization was far less influential in depth and in breadth. On the other hand, for policymakers,

30 such relationship matters to the appropriateness of trade and industrial policies intended to create

31 a favored environment for the U.S. domestic T\&A industries. In particular, trade restrictions

32 stemmed from grave concerns about the negative impacts of import penetration. This perspective

33 dominated U.S. textile trade policy for decades, resulting in the creation and implementation of

34 various policy tools for the purpose of trade restriction (Dickerson, 1988). However, if imports

35 no longer pose a threat to the survival of the domestic industry, but rather the two have become

36 "partners," then a fundamental shift in the direction of policy might be suggested.

37 Although some studies have been conducted on related topics, research gaps still exist. For

38 example, some studies either focused on the patterns of U.S. T\&A imports (such as Nordas, 39 2004) or explored the new business models of U.S. T\&A firms as a result of adopting various 40 restructuring strategies such as capitalization, mergers and acquisitions and outsourcing (such as

41 Christoffersen \& Datta, 2004; Kilduff, 2005; Parrish, Cassill, \& Oxenham, 2006). However, little

42 research has focused on imports as a potentially positive factor in the operation of today's U.S.

43 T\&A industries.

44 This paper tried to fulfill the current research gaps by linking the level of import penetration

45 with the operation of the U.S. T\&A industries between 2002 to 2008 . Specifically, two research 46 questions were studied: 
47 1. By adopting the various industry restructuring strategies, do the U.S. domestic textile and

48 apparel industries respectively incorporate imports into their operations?

492 Is the rising import penetration level still positively associated with the decline of the

50 domestic U.S. textile and apparel industries after various industry restructuring strategies were

51 adopted?

52 To be noted, the level of import penetration shall not be simply treated as the absolute

53 volume of imports. This is because import penetration is determined jointly by the import

54 volume and the level of apparent consumption in the importing country (Morgan, 1988, p. 13).

55 Compared to the volume of imports, import penetration can more accurately reflect the role of

56 imports in fulfilling the market demand relative to the domestic supply in the importing nation.

57

$58 \quad$ Literature Review

59 Import competition: theoretical views

60 Many studies in this area referred to the difficult time faced by the U.S. T\&A industries

61 over the past decades as the direct result of the intensive competition from rising imports

62 (Christoffersen \& Datta, 2004; Hodges \& Karpova, 2006). Some classic trade models are

63 helpful in explaining why the U.S. T\&A industry appeared to be negatively affected by rising

64 imports, especially those less costly ones produced in the low-wage developing countries.

65 According to the Hecksher-Ohlin model (H-O model), countries usually export products for

66 which it has abundant factors of production and import products for which it has scarce factors

67 (Batra \& Casas, 1973). As a capital-abundant country, the United States might be expected to

68 specialize in producing comparatively capital intensive products such as machineries. These

69 products would be exchanged for comparatively labor-intensive T\&A products through trade 
70 with less-developed countries having more abundant, less costly labor. Despite the overall

71 welfare gains in the United States, the H-O model suggested the "unfavorable" consequences for

72 the import-competing T\&A sector in terms of the lowered relative price in the U.S. market and

73 decreased domestic output.

74 The factor-price equalization theorem (H-O-S model) developed by Paul Samuelson

75 suggested that international trade will not only equalize the relative price of trading goods, but

76 also will equalize the factor price in these countries both in relative and absolute terms (Salvatore,

77 2004). This conclusion implies that when importing T\&A from lower-wage less developed

78 countries, wage levels in the U.S. T\&A industries will be "forced" to go downward until

79 reaching the same level with less-developed countries (Baldwin, 2008).

80 The Rybczynski theorem further argues that holding the price of trading goods in a country

81 constant, the increase of one production factor will result in disproportionally more production of

82 the product intensively using that production factor (Krugman, 2005). Based on the Rybezynski

83 theorem, much quicker capital growth in relation to the labor force in the United States will

84 result in disproportionate reduction of comparatively labor-intensive T\&A production.

85 Import penetration and heterogeneity of the U.S. T\&A industries

86 Historically the U.S. T\&A industries, especially the textile sector, unswervingly called for

87 restricting the flood of imports dominating the U.S. domestic market. However, data suggest that

88 the status of import penetration in some segments of the U.S. T\&A industries may different from

89 public perception. By the end of 2008, IPR in the U.S. textile industry (defined by North

90 America Industry Classification System NAICS 313 in this study) was still at a relatively modest

91 level of $29.1 \%$ measured by gross output and $17.9 \%$ measured by shipment (U.S. Census Bureau,

92 2010; U.S. International Trade Commission, USITC, 2010). This figure means that the majority 
93 of market demand for fiber, yarn, thread and fabrics in the United States was still supplied by the

94 U.S.-made textiles instead of by imports. In comparison, the IPR in the U.S. apparel industry

95 (defined by NAICS 315 in this study) was at a much higher level of $84.3 \%$ by gross output and

$9679.5 \%$ by shipment. On the other hand, although IPR in both textile and apparel industries are on

97 the rise over the past 10 years, the growth rate is much lower for the textile industry compared to

98 the apparel industry. From 2000 to 2008, IPR in the U.S. textile industry only gained 8.9

99 percentage points while imported apparel gained more than 20 percentage points in additional

100 market share (U.S. Census Bureau, 2010; USITC, 2010).

101 The disparity of the U.S. textile industry and the apparel industry in terms of their IPR level

102 reflects the heterogeneous nature of the two industries. In general, textile manufacturing is

103 comparatively more capital and technology intensive than apparel manufacturing (Nordas, 2004).

104 Because of the abundance in capital factors, the United States enjoys more comparative 105 advantage in relatively capital-intensive textile production in relation to imports from labor106 abundant less-developed countries. Similarly, import penetration ratio is higher in the U.S. 107 apparel industry because of the more labor-intensive nature of apparel production which favors 108 less-developed countries.

109 Structural change of the U.S. T\&A industries

110 The heterogeneity of textile and apparel production further affects the nature of structural 111 change and selection of restructuring strategies by the two industries. In terms of the U.S. textile 112 industry, first, the industry boosted production by investing in new machines, equipment, and 113 technology (Christoffersen et al., 2004). Capital intensity of the industry measured by the capital114 labor ratio, increased by nearly 20\% from 2002 to 2008 (U.S. Census Bureau, 2010). 115 Capitalization and investment in technology also led to the higher productivity and lower cost of 
116 textile production (Levinsohn \& Petropoulos, 2001). Datta \& Christoffersen (2005) suggested

117 that labor saving technical progress helped the U.S. textile industry improve its productivity by

$1182.1 \%$ and reduced production cost by 2.4\% annually from 1953 to 2001 .

119 Second, many U.S. textile firms enlarged production capacity through mergers and 120 acquisitions (M\&A) with the main purposes of taking advantage of economies of scale and

121 achieving lower production cost (Mock, 2002). The adoption of the M\&A strategy may explain

122 why large firms remain a good proportion in the U.S. textile industry despite the overall decline

123 of the total number of firms (Christoffersen et al., 2004). Empirical studies further suggested that

124 plants that survived in the U.S. textile industry emerged with stronger competitiveness while

125 those that exited were comparatively less productive (Chi, Kilduff, \& Dyer, 2009).

126 Third, the U.S. textile mills improved supply chain management. As customers' demands for 127 apparel products have become more volatile and unpredictable with a shorter life cycle, textile 128 production is expected to be more "sensitive" to quick market changes (Christopher, Lowson \& 129 Peck, 2004). Two main categories of strategies have been widely adopted in the U.S. textile 130 industry: one category is lean supply with the goal of reducing inventories and shortening the 131 delivery time, and the other is agile supply which intends to deliver the products more 132 "efficiently" by making the high volatility products available to the customers (Oh \& Kim, 133 2007). Specific supply chain management strategies commonly applied by the U.S. textile 134 industry include quick response (QR), automatic replenishment, just-in-time (JIT) systems, point 135 of sale information, and mass customization (Oh \& Kim, 2007).

136 Fourth, the U.S. textile industry actively engaged in the building of regional production 137 networks with countries that are geographically close to the United States. This strategy received 138 strong support from U.S. trade policymakers by intentionally adding special provisions 
139 encouraging the use of United States-made yarns or fabrics in the preferential trade agreements

140 reached with trading partners (Gereffi, Spener \& Bair, 2002). In these agreements, imports from

141 partner countries receive preferential tariff treatment. By the end of 2009, the United States had

142 reached eleven such free-trade agreements and four preferential trade agreements with less-

143 developed countries mostly located in the Americas. Statistics from the Office of Textile and

144 Apparel (OTEXA) indicated that from 2000 to 2009, more than 50\% of U.S. textile mill exports 145 went to partners under the NAFTA and DR-CAFTA.

146 Compared with the U.S. textile industry, the U.S. apparel industry had a more difficult

147 time facing the flood of imports coming from the low-wage countries. High domestic production

148 cost, especially labor, is regarded as one of the greatest disadvantages for the U.S. apparel

149 industry to compete on price (Gereffi et al., 2002). On the other hand, contrary to the case in the

150 textile industry, the nature of apparel manufacturing makes it quite difficult to incorporate

151 automation (Dickerson, 1999).

152 Over time as retailers bought increasing quantities of low cost imports, the fierce

153 competition caused the U.S. apparel industry to abandon most of the domestic production

154 capacity in favor of outsourcing and offshore sub-contracting (Kim \& Rucker, 2005). Gereffi et

155 al. (2002) proposed that two types of apparel firms emerged quickly in the industry: one is 156 "marketers," which are engaged in design and marketing activities and characterized as 157 manufacturers without factories (such as Liz Claiborne (prior to name change) and Ralph 158 Lauren). The other type is "branded manufacturers" which still deal with activities ranging from 159 design, cutting, assembly, laundry to marketing (such as Levi Strauss and VF Corporation). 160 However, the key role of "branded manufacturers" is to organize and oversee the whole 161 production process rather than simply manufacture by themselves (Gereffi et al., 2002). Over 
162 time, these distinctions are less clear, however, for both "marketers" and "branded

163 manufacturers," or other types that emerge, their operations are based on the close contracting

164 networks with overseas companies, especially manufacturers in the less-developed countries.

165 These transformed U.S. apparel firms did not regard imports as competitors. Quite the opposite, 166 a large portion of U.S. apparel imports actually were arranged by “marketers” and "branded 167 manufacturers.”

168 Ironically, U.S. retailers became the emerging competitors for U.S. apparel firms. Although 169 retailers were the customers of apparel firms, they became ambitious in establishing their own 170 sourcing network so as to shorten the lead time, reduce the sourcing cost, and enhance their 171 margins (Gereffi et al., 2002; Dickerson, 1999). At the same time, some large-scale-U.S. apparel

172 firms, including branded manufacturers have also extended their business realm into the retailing 173 sector by means of forward integration (Kilduff, 2005). The phenomenon of "scrambled 174 softgoods chain” within which some traditional steps in the supply-chain are skipped may also be 175 found in the U.S. apparel industry (Dickerson, 1999).

176 On the other hand, although imported apparel through sourcing networks has played a 177 dominant role in supplying the U.S. apparel market, the U.S. apparel industry still maintains 178 certain local production bases, such as in New York and Los Angeles (Bailey-Todd, Eckman, \& 179 Tremblay, 2008). Compared with imports which target the mass market and achieve profits on 180 high volumes, this locally produced apparel, in most cases, serve a U.S. niche market. They cater 181 to particular needs from the retail customers on quality and flexibility and compete mostly on 182 non-price factors, such as design and service (Parrish et al., 2006). 
Figure 1 and Figure 2 present the conceptual models illustrating the theoretically-suggested

186 relationship between import penetration and the operation of the U.S. T\&A industries when

187 taking their respective restructuring strategies into consideration.

In terms of the U.S. textile industry (Figure 1), most of its restructuring strategies intend to

191 focus on building a stronger domestically-based production capability rather than offshore 192 production (Kilduff, 2005). This makes the U.S. domestic apparel manufacturers remain 193 important customers ${ }^{1}$ to the U.S. textile industry. However the rising import penetration ratio 194 means the U.S. domestic demand for textiles is fulfilled by a growing volume of imports rather 195 than U.S.-made textile products. The loss of market share suggests the U.S. textile industry 196 suffers from rising imports. Therefore, this study proposes: competes with imports. Therefore, a higher import penetration ratio shall be positively associated with the decline of the U.S. textile industry and vice versa. strategies, it has achieved global operations with traditional manufacturing-oriented functions 204 largely replaced by offshore production and outsourcing (Kilduff, 2005). Under the new business 205 model, on one hand, a good proportion of imports were brought into the U.S. market by the U.S. 206 apparel firms themselves, whose commercial success was heavily dependent on the efficient 207 cooperation with contracted apparel manufacturers overseas. On the other hand, as the 
transformed U.S. apparel industry treats imported apparel as an integral part of the supply chain

209 instead of competitors, the rising import level reflected by a higher import penetration ratio may

210 no longer imply the U.S. apparel industry "lost” in competing with imports. Although certain

211 domestic apparel manufacturing capacity remained in the United States, in most cases these

212 operations fulfill the needs of the niche market and are supplementary to the imports which

213 basically serve the mass consumer markets (Gereffi, 2001). As the nature of the game has largely

214 changed from zero-sum competition into cooperation, operation of the restructured U.S. apparel

215 industry shall not be negatively affected by rising imports. Therefore, the study proposes:

216 Hypothesis 2: After restructuring, the U.S. domestic apparel industry no longer

217 competes with imports. Therefore, a higher import penetration ratio shall be either

218 negatively or neutrally associated with the decline of the U.S. apparel industry and vice

219 versa.

220

221 Methodology

222 Empirical Model Structure

223 This study develops a revised model based on the work of Greenaway, Hine \&Wright (1999)

224 to empirically test the hypothesis. First, assume for a 4-digit NAICS industry $i$ in period $t, Q_{i t}^{s}$

225 represents the domestic supply of U.S. T\&A industries, $Q_{i t}^{d}$ represents the total U.S. market

226 demand. Import supply $M_{i t}$ is defined as the difference of U.S. market demand and domestic

227 supply. Based on the common definition, such as that used by Morgan (1988), import penetration

228 ratio $\left(I P R_{i t}\right)$ is calculated as the share of imports within the total U.S. demand:

229

$$
I P R_{i t}=\frac{M_{i t}}{Q_{i t}^{d}}=\frac{Q_{i t}^{d}-Q_{i t}^{s}}{Q_{i t}^{d}}=1-\frac{Q_{i t}^{s}}{Q_{i t}^{d}}
$$


231 production function is $Q_{i t}^{s}=A_{i t}^{\lambda} K_{i t}^{\alpha} \cdot L_{i t}^{\beta}$, where $A_{i t}^{\lambda}$ denotes total factor productivity which

232 changes over time; $\mathrm{K}$ and $\mathrm{L}$ respectively represents capital and labor input with output elasticity 233 at $\alpha$ and $\beta$.

234 To maximize profit, marginal revenue product of labor (MPL) of industry $i$ in period $t$ shall 235 equal its wage $\left(W_{i t}\right)$ level and marginal revenue product of capital (MPK) shall equal rent $\left(C_{i t}\right)$. 236 As most concerns for the impacts of import competition are concentrated on the labor side, $\mathrm{K}$ is

237 further expressed as a function of parameter L, W and C, so that $Q_{i t}^{s}$ will be directly dependent 238 on employment and wage level. By solving equations simultaneously, we get

$$
K_{i t}=\frac{P_{i t} \alpha Q_{i t}^{s}}{C_{i t}}=\frac{P_{i t} \alpha L_{i t} W_{i t}}{P_{i t} \beta C_{i t}}=\frac{\alpha L_{i t} W_{i t}}{\beta C_{i t}}
$$

Third, in term of the behavior of U.S. total domestic demand for industry $i$ in period $t$,

241 assume $Q_{i t}^{d}=B \cdot P_{i t}^{b_{1}} \cdot Y_{t}^{b_{2}}$, where $P_{i t}$ denotes the market price of industry $i$ in period $t ; Y_{t}$ is the

242 real national income of the United States. $b_{1}$ measures the price elasticity of demand in a ceteris

243 paribus condition, i.e. the percentage change of demand for industry $i$ given one percentage

244 change of market price when other factors hold constant; $b_{2}$ measures impact of aggregate

245 income elasticity for industry $i$, i.e., the percentage change of the U.S. demand for industry $i$ 246 given one percentage change of U.S. national income. B is constant.

247 Finally, replacing $Q_{i t}^{s}$ and $Q_{i t}^{d}$ in Equation 2 and taking logarithm of both sides, we have:

$$
\operatorname{Ln}\left(1-I P R_{i t}\right)=\phi_{0}+\phi_{1} \operatorname{Ln}\left(A_{i t}\right)+\phi_{2} \operatorname{Ln}\left(L_{i t}\right)+\phi_{3} \operatorname{Ln}\left(W_{i t}\right)+\phi_{4} \operatorname{Ln}\left(P_{i t}\right)+\phi_{5} \operatorname{Ln}\left(Y_{t}\right)
$$


In particular, we are interested in the value of the following parameters:

- $\phi_{1}$ (elasticity of supply associated with productivity): which measures the impact of productivity change of the U.S. domestic T\&A industries on its market share in relation to imports in the U.S. market. As productivity is positively associated with the supply of U.S.-made T\&A, when imports directly compete with U.S. product, productivity growth will result in the rising market share of U.S. domestic products. Therefore, we expect $H_{0}: \phi_{1}>0 ; H_{1}: \phi_{1} \leq 0$ for the U.S. textile industry; and $H_{0}: \phi_{1} \leq 0 ; H_{1}: \phi_{1}>0$ for the U.S. apparel industry. relation to imports. As in the case of productivity growth, when imports directly compete with U.S. products, the increase of labor supply will result in domestic supply increasing market shares. Therefore, we expect $H_{0}: \phi_{2}>0 ; H_{1}: \phi_{2} \leq 0$ for the U.S. textile industry; and $H_{0}: \phi_{2} \leq 0 ; H_{1}: \phi_{2}>0$ for the U.S. apparel industry. T\&A industries on its market share in the United States in relation to imports. When productivity is held constant, the rising wage level should be the result of rising product price as $M P L=M L \cdot P=W$. If imports directly compete with U.S. products, in this occasion, supply curve of the U.S. domestic T\&A industries will decline. Therefore, we expect $H_{0}: \phi_{3}<0 ; H_{1}: \phi_{3} \leq 0$ for the U.S. textile industry; and $H_{0}: \phi_{3} \geq 0 ; H_{1}: \phi_{3}<0$ for the U.S. apparel industry. 
- $\phi_{4}$ (elasticity of price elasticity): which measures the impact of market price on the market share of U.S. domestic made T\&A products. When imports directly compete with U.S. products and both demand and supply are held constant, rising market price will encourage U.S. domestic T\&A industries to increase supply and leave less demand for imports to fulfill. Therefore, we expect $H_{0}: \phi_{4}>0 ; H_{1}: \phi_{4} \leq 0$ for the U.S. textile industry; and $H_{0}: \phi_{4} \leq 0 ; H_{1}: \phi_{4}>0$ for the U.S. apparel industry. $H_{1}: \phi_{5}>0$ for the U.S. apparel industry. For the empirical test, two additional variables are included in Equation 3.

- $\phi_{5}$ (elasticity of demand/income elasticity): which measures the impact of aggregate demand of the United States (aggregate income) on the share of its domestic-made T\&A products in the market. Enlarged domestic demand will raise the market price and result in more domestic supply. Therefore, when imports directly compete with U.S. products, we expect $H_{0}: \phi_{5}>0 ; H_{1}: \phi_{5} \leq 0$ for the U.S. textile industry; and $H_{0}: \phi_{5} \leq 0$;

One is the dummy variable Quota, which is used to capture the potential impacts of the elimination of the quota system on the import penetration level. As variable Quota $=0$ for years 2002-2004 and Quota=1for years 2005-2008, parameter $\phi_{6}$ can reveal whether IPR has any structural changes in the post-quota era due to the significant changes of the” rules of game.”

289 Another variable is $t$, which is used to capture the potential time trend that existed in the data. 290 Failing to control the time trend may result in a spurious regression problem (Wooldridge, 2002), 291 especially when time-series data are not stationary.

292 Besides, $c_{i}$ refers to the possible unobserved sectoral effect and $\mu_{i t}$ denotes error terms. 293 Because of the interconnection between the textile industry and the apparel industry, simply 
294 simulating the Equation 3 individually for each 4-digit NAICS code is likely to result in biased

295 estimation of parameters due to the correlation among $\mu_{i t}$ for different textile and apparel 296 subsectors (Wooldridge, 2002).

297 To achieve unbiased and consistent estimation, the panel data modeling technique is 298 adopted in this study, which is specifically developed to tackle a dataset involving both cross299 sectional and time-series data. Compared to the traditional cross-sectional regression, a panel 300 data model can help solve the potential problem of cross-sectional heteroskedasticity in the 301 dataset and reveal the potential dynamics in the dataset which cannot be detected by the cross302 sectional regression (Wooldridge, 2002). Moreover, the generalized least square (GLS) method 303 instead of pooled ordinary least square (POLS), is used to ensure consistent and efficient 304 estimation of the parameters. GLS has the advantages of tolerating a certain degree of correlation 305 among independent variables (Wooldridge, 2002). This is particularly useful in this study given 306 the linkage among productivity, wage level and employment size in Equation 3.

307 Data Source

308 Data used in this study came from various U.S. government agencies, which are the best 309 sources available for official national-level aggregated industry and trade statistics. Except for 310 otherwise noted, all data were collected at the 4-digit NAICS code level ${ }^{1}$, so as to make industry 311 performance and trade activities compatible with each other. More specifically:

312 For import penetration ratio (variable IPR), volumes of imports for each 4-digit NAICS 313 code sectors were measured in dollar terms (USITC, 2010). Domestic supply of each 4-digit 314 NAICS code U.S. T\&A industry was measured by the total value of shipments (U.S. Census, 315 2010). In particular, by the U.S. Census's definition, value of shipment means the total value of 316 all products shipped by the producers (U.S. Census, 2010). Therefore, this index is more 
317 appropriate than production output to reflect the U.S. domestic supply of textiles and apparel in 318 the market. Employment level (variable $L$ ) was measured by the total number of employees (U.S.

319 Department of Labor, 2010a). Wage level (variable $W$ ) was measured by the average hourly 320 earnings of all employees either in the U.S. textile industry or in the apparel industry (U.S. 321 Department of Labor, 2010a). Productivity (variable $A$ ) was measured by the productivity index 322 (year 2002=100) (U.S. Department of Labor, 2010b). According to the Bureau of Labor 323 Statistics, definition, labor productivity is the "ratio of output of goods and services to the labor 324 hours devoted to the production of that output.” Producer price index (PPI) was used as the 325 proxy for market price (variable P ) (U.S. Department of Labor, 2010b). According to the 326 definition of BLS, PPI measures the average change over time in the selling prices received by 327 domestic producers for their output (U.S. Department of Labor, 2010c). Last but not least, 328 aggregate demand (income) in the United States was measured by Gross Domestic Product (U.S. 329 Department of Commerce, 2010).

330 Data used in this study range from 2002 through 2008. Year 2002 was the first time when 331 statistics collected based on NAICS were available. Prior to that, industry activities in the United 332 States were collected based on the Standard Industrial Classification (SIC) system, whose 333 industry classification method was different and incompatible with NAICS. Further, because of 334 time lag in availability of government data at the time of the study the latest statistics based on 335 NAICS was through 2008.

\section{Results and Discussions}

338 Relationship Between Imports and the U.S. T\&A Industry: Empirical results 
First, the Breusch and Pagan Lagrangian Multiplier (BP) test was conducted to see whether unobserved sectoral effect $c_{i}$ was present. As Chi-square of the BP test is $58.00(p=0.01)$,

341 therefore at 95\% confidence level we reject the null hypothesis, i.e., unobserved sectoral effect

$342 C_{i}$ was suggested present in the empirical model (5).

343 Second, the Hausman test was conducted to see whether the unobserved sectoral effect $C_{i}$ was

344 correlated with other independent variables in Equation 3. For the U.S. textile industry, Chi345 squares of the Hausman test is $5.0(p=0.08)$, therefore at $95 \%$ confidence level, we fail to reject 346 the null hypothesis, i.e. sectoral effect $c_{i}$ is suggested uncorrelated with other independent

347 variables. In such case, both the fixed effect model (FE) and the random effect model (RE) can

348 generate consistent estimation. However, RE estimation usually is more efficient than FE 349 (Wooldridge, 2002), therefore RE is chosen for studying the U.S. textile industry. For the U.S. 350 apparel industry, Chi-squares of the Hausman test is $10.57(p=0.01) \quad P$-value $=0.01<0.05$, 351 therefore at 95\% confidence level, we reject the null hypothesis. Fixed effect model (FE) 352 therefore is chosen for studying the U.S. apparel industry and its relationship with import 353 penetration level.

354 Third, RE and FE models were run by STATA 10.0 and the estimation results were shown 355 in Table 1 (A) and (B). For both RE and FE model, $P$-value of the F-statistics were smaller than $356 \quad 0.01$ at the $95 \%$ confidence level. This suggests that overall the dependent variable $3571-I P R_{i t}$ which measures the share of U.S. domestic-made T\&A in the U.S. market, has strong 358 correlation with independent variables describing the operation of the U.S. textile and apparel 359 industries, namely productivity, employment, wage level, market price and GDP. 
According to Table 1 (A), Hypothesis 1 which suggests a “competing” relationship

362 between imports and the U.S. domestic textile output was not supported. In most cases, import

363 penetration level seems independent of the operation of the U.S. textile industry. Changes of the

364 productivity and wage level of the U.S. textile industry were both suggested having no

365 statistically significant impacts on the changes of the import penetration level. Neither did the

366 market price nor aggregate U.S. demand show a significant relationship with the import

367 penetration level. The only exception occurs in the case of employment. Results in Table 1 (A)

368 imply that expansion of the workforce in the U.S. textile industry will not help the U.S. textile

369 industry gain more market share in the domestic market, but rather will end up with more

370 imports. Moreover, the estimated parameter for the dummy variable quota is not statistically

371 significant, suggesting that impact of the quota elimination did not lead to changes of the import

372 penetration level in the U.S. textile industry as a whole.

373 Hypothesis 2 was supported by the empirical results shown in Table 1 (B). Overall, results

374 suggested the operation of the U.S. apparel industry and imports were "immune” to each other.

375 Variables describing operation of the U.S. apparel industry were mostly found having no

376 statistically significant impacts on the relative market position of imports in relation to U.S.

377 domestic output. This means a rising import penetration in the U.S. market was not associated

378 with negative development of the U.S. domestic apparel industry. Moreover, empirical results

379 suggest that holding other variables constant, 1\% change of the U.S. market price would result in

$380 \quad 0.5 \%$ decline of the market share of the domestic output in the same direction. This means

381 imports will continue increasing when output of the U.S. domestic-made apparel moves toward

382 the higher-end of the market. On the other hand, as the case in the U.S. textile industry, no 
383 evidence shows that elimination of the quota system had resulted in change of the overall level of

384 U.S. apparel imports².

385

386 Discussion

387 Despite some inconsistencies with the two hypotheses, results of the empirical tests may still

388 be explained by certain factors. For the U.S. textile industry, first, with shrinkage of U.S. 389 domestic demand, operation of the U.S. textile industry relied more heavily on its performance in 390 overseas markets. With a growing proportion of industry output shipped outside the U.S. border, 391 it may explain why import penetration ratio could still rise when the U.S. domestic fiber, yarn 392 and thread mills improve productivity, enlarge employment, and raise wage level. When the U.S. 393 textile industry no longer specifically targets the domestic market, it seems reasonable that 394 neither the rising market price nor the expanded aggregate demand (income) in the United States 395 results in more industry supply.

396 Second, although the U.S. textile industry still largely focuses on domestic production after 397 the adoption of various restructuring strategies, the industry may still have undergone substantial 398 structural changes reflected on the nature of its output. Statistics show that, only $14 \%$ of the total 399 U.S. fiber output was used for apparel production by the end of 2008, reduced from 18\% in 2004 400 (Fiber Organon, 2009). In comparison, technical textiles which was widely used in military, 401 healthcare/medical, construction, engineering and agriculture industries (Dickerson, 1999; Chi, 402 2010), accounted for $41 \%$ of total fiber usage in the United States in 2008, increased from $34 \%$ 403 in 2004 (Fiber Organon, 2009). It is likely that although imported textiles and the U.S. domestic 404 textile output were counted under the same 4-digit NAICS code, they were heterogeneous in 405 nature with different end-use purposes. 
As for the U.S. apparel industry, first, the results may due to the fact that the U.S. domestic

407 apparel output and imported apparel target different segments of the U.S. market. As proposed in

408 Figure 2, while imports largely fulfill the demand from mass market, the U.S. domestic-made

409 apparel has narrowed their focus to niche markets in the United States whose preferences give 410 more weight to added values, services or speed of product delivery that cannot be easily fulfilled

411 by imports (Parrish et al, 2006). Some niche markets are created by U.S. legislation, such as the

412 Berry Amendment ${ }^{3}$. When target markets had little in overlap, it is not too surprising to see that

413 operation of the U.S. apparel industry had minimum impact on the ebb and flow of imports.

414 Second, statistical insignificance of the empirical results could also attribute to the fact that

415 multiple parties in the U.S. softgoods industry are involved in importing apparel. In particular, it

416 has become a common practice for large apparel retailers in the United States to set up

417 departments solely responsible for global sourcing of an increasing share of private-label

418 products in their total sales (Dickerson, 1999). However, under the NAICS system, apparel

419 retailers (NAICS 448) and apparel firms (NAICS 315) were classified separately, which means

420 their industry activities such as output, productivity and employment were independently

421 collected and released. Unfortunately retailers' participation in international trade currently is

422 not traced and reported by official statistical sources. Since apparel imports sourced by retailers

423 have reached a sizable scale but cannot be separated from total import volumes, it unavoidably

424 weakens the sensitivity of data in reflecting the actual linkage between imports and the operation

425 of the U.S. apparel industry (NAICS 315).

426 Third, the diversity of apparel products may further complicate the empirical estimation of

427 the relationship between imports and the operation of the U.S. domestic firms. In contrast to the 428 highly standardized textiles products such as fiber, yarn and fabric, apparel products are more 
429 heterogeneous in nature due to consumers' seeking of uniqueness. Apparel imports from 430 different sources have demonstrated a wide range of average price measured by dollars per

431 square meters (SME). Some studies already argue that origin of imports matters for their impact

432 on an importing country's domestic industries (Bernard, Jensen, \& Schott, 2006). Similarly, the

433 proposed cooperation between imports and the operation of the U.S. apparel industry could be

434 more remarkable if empirical tests were narrowed down to a smaller group of apparel firms and 435 imports from certain geographic regions.

\section{Conclusions and Implications}

438 This study empirically evaluated the relationship between import penetration and the

439 operation of the U.S. textile and apparel industries by using a panel data model based on data at 440 4-digit NAICS code ranging from 2002 through 2008.

441 First, the random effect model suggests that overall the U.S. textile industry formed a weak 442 cooperative relationship with imports in the U.S. market. Specifically, employment size of the 443 U.S. textile industry was found negatively associated with its market share in relation to imports 444 in the U.S. market. However, no evidence showed that productivity and wage level of the U.S. 445 domestic textile industry nor the aggregate demand in the United States had statistically 446 significant impacts on the import penetration level in the U.S. textile market. Nor was the 447 elimination of the quota system in 2005 shown to have statistically significant impact on the 448 overall import penetration level in the U.S. textile market.

449 Second, the fixed effect model suggests that the U.S. apparel industry overall formed a 450 neutral relationship with imports in the U.S. market. No evidence indicated that productivity, 451 employment and wage level of the U.S. domestic apparel industry as well as the aggregate 
452 demand in the United States had statistically significant impacts on the import penetration level

453 in the U.S. apparel market. However, market price was found negatively associated with the

454 share of U.S. domestic-made apparel in the U.S. market. Similar to the case in the U.S. textile

455 industry, impact of the quota elimination on the import penetration level in the U.S. apparel 456 market was found not statistically significant.

457 Findings of this study have several important implications both regarding the evolution of 458 the U.S. textile and apparel industries and many broader issues critical to the global economy 459 and its governance in the $21^{\text {st }}$ century. First, results of this study present a somewhat more 460 encouraging picture of the current status of the U.S. textile and apparel industries than many 461 previous studies suggested. Although pessimistic and stereotyped public images of a dying U.S. 462 textile and apparel industry are to an extent still popular, this study argues that the two industries 463 overall have stabilized as a result of their sweeping restructuring. In particular, indexes often 464 used to measure the size of an industry such as employment and output may not be solely 465 appropriate for evaluating an industry which is undergoing significant structural changes. 466 Instead, a more comprehensive and objective assessment of the conditions of the U.S. textile and 467 apparel industries should also take aspects such as product structure, productivity growth, 468 demand for occupations at different skill levels and export dependency rate into consideration.

469 Overall, it is important to keep in mind that both the U.S. textile and apparel industries today are 470 but a shadow of what they were even a decade ago. However, the two industries have survived 471 through strategic transformation and are expected to continue development in the future.

472 Second, findings of this study raise questions on whether there is a basis to be nervous 473 about rising imports, especially in the context of an integrated global economy in which global 474 fragmented production and trade networks predominate. Actually, the validity of arguments 
475 stressing the adverse impacts of rising imports largely depends on the assumption that imports

476 and output of importer’s domestic industry necessarily constitute a “zero-sum” game. However,

477 this assumption is questionable when international trade in an integrated global economy today is

478 no longer arm's-length transaction in nature (Cattaneo, Gereffi \& Staritz, 2010). Findings of this

479 study also pose challenges to the “zero-sum” game assumption. The suggested non-competing

480 relationship implies that not only has the U.S. apparel industry extensively incorporated imports

481 into its global-based operation, but also the U.S. textile industry may benefit from imports and

482 offshore production, although the detailed mechanism needs further exploration.

483 Perhaps findings of this research call for shifting the orientation of U.S. textile and apparel 484 trade policy from focusing on import restriction to greater export promotion. To a large extent, 485 curbing the growth of imports dominates the history of the U.S. textile and apparel trade policy 486 over the past 40 years. Such single-focused policy orientation reflects certain policymakers’ 487 strong suspicion, skepticism and deep anxiety about rising imports and their presumed negative 488 impacts on the health of the U.S. domestic industries. However, evidence provided in this study 489 shows that with the adoption of various restructuring strategies, maintaining today's U.S. textile 490 and apparel industries largely depend on the free flow of goods and services across the borders. 491 Even if imports were restricted, those lost jobs-mostly low-skill types, would not simply go 492 back to the United States as wished. Instead, with the rising dependency on markets outside the 493 U.S. border, perhaps policymakers should more wisely spend precious policy resources to 494 strengthen the competiveness of U.S. textiles and apparel products in the global marketplace 495 which is of growing importance to the industries' future prosperity.

496 Despite the interesting and meaningful results of the findings, several changes might be 497 made to further improve the quality of the future similar studies. First, it could be better if longer 
498 time-series data were available. A longer time-series data will help improve the overall reliability

499 of the estimation by increasing the number of data points and degrees of freedom for the model.

500 However, cautions should also be given to the possible new "noises" brought in with data from a

501 longer time span. For example, if data prior than 2002 were used in the model, questions arise on

502 how to deal with China's WTO accession effect as well as the correspondence of NAICS with

503 the SIC system because categories changed. Second, it could be improved if empirical tests can

504 be conducted at even more disaggregated data level. Particularly, the heterogeneity of different

505 sub-sectors within the textile and apparel industries might also cause the insignificance of the

506 estimation results. Third, the study might be improved if the interactions between the textile

507 industry and the apparel industry can be taken into consideration. In this study, the relationship

508 between imports and the operation of the U.S. textile and apparel industries were evaluated based

509 on products within the same NAICS-code sector, while future study may take cross-sector

510 connections into consideration. Last but not least, structure of the empirical model can be further

511 improved by taking the potential existence of stochastic trends in the dataset into consideration.

512 With the presence of stochastic trends, the dataset will be non-stationary and may lead to biased

513 estimation even when time trend variable $t$ is included in the model. As one solution, the Dickey-

514 Fuller test or related tools may be used in the future to detect the potential existence of stochastic

515 trends.

Note

517 1. In this study, the U.S. textile industry covers NAICS 3131 (Fiber, yarn and thread), NAICS

5183132 (Fabrics) and NAICS 3133 (Fabric finishing and coating); the U.S. apparel industry

519 covers NAICs 3151 (Knitted apparel), NAICs 3152 (Cut and sew apparel) and NAICS3159

$520 \quad$ (Apparel accessories). 
521 2. The "insignificant" results may be due to two major reasons. First, quota elimination may

522 exert more significant impact on the country structure of import sources rather than the

523 overall import volume which is more closely related to macro economic conditions (Nordas,

524 2004). Second, the largest textile and apparel exporter to the United States—China, was still

525 subject to quota restriction for many of its most competitive products until the end of 2008.

526 3. Under the Berry Amendment, clothing, fabrics, fibers, yarns or other made-up textiles

527 procured by the U.S. Department of Defense (DoD) need to be $100 \%$ made in the United

528 States (U.S. Department of Defense, 2011).

529

\section{References}

530 Abernathy, F. H., Volpe, A., \& Weil, D. (2006). The future of the apparel and textile industries: 531 prospects and choices for public and private actors. Environment \& Planning A, 38(12), 2207-2232.

533 Bailey-Todd, A., Eckman, M., \& Tremblay., K. (2008). Evolution of the Los Angeles County apparel industry. Journal of Fashion Marketing and Management, 12(2), 260-276.

535 Baldwin, R. E. (2008). The development and testing of Heckscher-Ohlin trade models: a review. $536 \quad$ Cambridge, Mass: MIT Press.

537 Batra, N., \& Casas, R. (1973). Intermediate products and the pure theory of international trade: a 538 Neo-Hecksher-Ohlin framework. The American Economic Review, 63(3), 297-311.

539 Bernard, A. B., Jensen, J. B., \& Schott, P. K. (2006). Survival of the best fit: Exposure to low540 wage countries and the (uneven) growth of U.S. manufacturing plants. Journal of $541 \quad$ International Economics, 68(1), 219-237.

542 Cattaneo, O., Gereffi, G., \& Staritz, C. (2010). Global value chains in a postcrisis world: A 543 development perspective. Washington, D.C: World Bank. 
544 Chi, T., Kilduff, P. Vidyaranya, B., \& Dyer, C. (2009). Business Environment Characteristics, 545 Competitive Priorities, Supply Chain Structures, and Business Performance: an empirical 546 study of the US technical textile industry. International Journal of Intercultural 547 Information Management, 1(4), 407-432.

548 Chi, T. (2010). An Empirical Study of Trade Competitiveness in the U.S. Technical Textile 549 Industry. Journal of Textile and Apparel, Technology and Management, 6(4), 1-17.

550 Christoffersen, S. \& Datta, A. (2004). The Changing Structure of U.S. Textiles: Productivity 551 Implications. The Journal of Business and Economic Studies, 10(2), 28-37.

552 Datta, A \& Christoffersen, S. (2005). Production costs, scale economies, and technical change in 553 U.S. textile and apparel industries. Atlantic Economic Journal, 33(2), 201-213.

554 Dicken, P. (2003). Global Shift: Reshaping the Global Economic Map in the 21st Century. New $555 \quad$ York: Guilford Press.

556 Dickerson, K. G. (1988). The textile sector as a special GATT case. Clothing and Textiles 557 Research Journal, 27(2), 17-25.

558 Dickerson, K. G. (1999). Textile and apparel in the global economy. Upper Saddle, N.J.: Merrill. 559 Fiber Organon. (2009, October). Fiber Economics Bureau, Roseland, NJ

560 Gereffi, G. (1999). International trade and industrial upgrading in the apparel commodity $561 \quad$ chain. Journal of International Economics, 48(1), 37-70.

562 Gereffi, G. (2001). Global sourcing in the U.S. apparel industry. Journal of Textile and Apparel 563 Technology and Management, 2(1), 1-5.

564 Gereffi, G., Spener, D., \& Bair, J. (2002). Free trade and uneven development: The North 565 American apparel industry after NAFTA. Philadelphia: Temple University Press. 
566 Greenway, D., Hine, R., \& Wright, P. (1999). An empirical assessment of the impact of trade on 567 employment in the United Kingdom, European Journal of Political Economy, 15, 485500

569 Hodges, N.N., \& Karpova, E. (2006). Employment in the U.S. textile and apparel industries: A 570 comparative analysis of regional vs national trends. Journal of Fashion Marketing and $571 \quad$ Management, 10(2), 209-226.

572 Kilduff, P. (2005). Patterns of strategic adjustment in the U.S. textile and apparel industries since 1979. Journal of Fashion Marketing and Management, 9(2), 180-194.

574 Kim, Y., \& Rucker, M. (2005). Production sourcing strategies in the U.S. apparel industry: A 575 modified transaction cost approach, Clothing and Textiles Research Journal, 23(1), 1-12.

576 Krugman, P. \& Obstfeld, M. (2005). International economics: Theory and policy. The AddisonWesley series in economics. Boston: Pearson Addison-Wesley.

578 Levinsohn, J., \& Petropoulos, W. (2001). Creative destruction or just plain destruction? The 579 U.S. textile and apparel industries since 1972. NBER working paper, no. W8348. Cambridge, MA: National Bureau of Economic Research.

581 Mock, G. N. (2002), The textile dye industry in the United States. Review of Progress in 582 Coloration and Related Topics, 32, 80-87.

583 Morgan, A. D. (1988). British imports of consumer goods: A study of import penetration 1974-5. Cambridge [Cambridgeshire]: Cambridge University Press.

585 Nordas, H. K. (2004). The global textile and clothing industry post the agreement on textile and $586 \quad$ clothing. WTO discussion papers, 5. Geneva: WTO Publications.

587 Office of Textile and Apparel, OTEXA. (2010). U.S. Imports of Textile and Apparel. Retrieved 588 on October 27, 2010 from http://www.otexa.ita.doc.gov/scripts/tqads2.exe/ctrypage 
589 Oh, H., \& Kim, E. (2007). Strategic planning for the U.S. textile industry in the post-quota era:

590 Achieving speed-to-market advantages with DR-CAFTA countries. Journal of Fashion $591 \quad$ Marketing and Management, 11(2), 246-269.

592 Parrish, E.D., Cassill, N.L. \& Oxenham, W. (2006). Niche market strategy in the textile and 593 apparel industries. Journal of Fashion Marketing and Management, 10(4), 420-432.

594 Salvatore, D. (2004). International Economics. New York: John Wiley \& Sons Inc..

595

596

U.S. Census Bureau, Census. (2010). The Manufacturers’ Shipments, Inventories and Orders

(M3). Retrieved Oct 3, 2010, from http://www.census.gov/manufacturing/m3/

598 U.S. Department of Defense. (2011). Berry Amendment FQA. Retrieved April 11, 2011 from http://www.acq.osd.mil/dpap/cpic/ic/berry_amendment_faq.html

600 U.S. Department of Labor, Bureau of Labor Statistics, BLS. (2010a). Employment, Hours and 601 Earnings. Retrieved October 2, 2010, from http://www.bls.gov/ces/

602 U.S. Department of Labor, Bureau of Labor Statistics, BLS. (2010b). Industry Productivity

603 Indexes. Retrieved October 2, 2010, from http://www.bls.gov/lpc/

604 U.S. Department of Labor, Bureau of Labor Statistics, BLS. (2010c). Producer Price Indexes. 605 Retrieved October 7, 2010, from http://www.bls.gov/ppi/

606 U.S. Department of Commerce, Bureau of Economic Analysis, BEA. (2010). Gross Domestic

607 Product (GDP) by Industry. Retrieved October 2, 2010, from

608 http://www.bea.gov/industry/index.htm\#annual

609 United States International Trade Commission, USITC. (2010). Interactive Tariff and Trade 610 DataWeb. Retrieved October 27, 2010, from http://dataweb.usitc.gov/

611 Wooldridge, J. M. (2002). Econometric Analysis Cross Section and Panel Data. Massachusetts Institute of Technology. 
Table 1 (A) Results of Random Effect Model on the U.S. Textile Industry

\begin{tabular}{lrrrrrrr}
\hline $\operatorname{Ln}\left(1-I P R_{i t}\right)$ & $\begin{array}{c}\text { Productivity } \\
\operatorname{Ln}\left(A_{i t}\right)\end{array}$ & $\begin{array}{c}\text { Employment } \\
\operatorname{Ln}\left(L_{i t}\right)\end{array}$ & $\begin{array}{l}\text { Wage } \\
\operatorname{Ln}\left(W_{i t}\right)\end{array}$ & $\begin{array}{c}\text { Market price } \\
\operatorname{Ln}\left(P_{i t}\right)\end{array}$ & $\begin{array}{c}\text { GDP } \\
\operatorname{Ln}\left(Y_{t}\right)\end{array}$ & $\begin{array}{r}\text { Quota } \\
\text { quota }\end{array}$ & $\begin{array}{c}\text { Time } \\
t\end{array}$ \\
\hline Textile & -0.018 & $-0.179^{* *}$ & 0.17 & 0.50 & -0.23 & 0.08 & -2.52 \\
$\quad$ industry & $(0.06)$ & $(0.04)$ & $(0.54)$ & $(0.45)$ & $(1.09)$ & $(3.75)$ & $(7.31)$ \\
Constant: 6.01(135.02)* & & & & & & & \\
P-value for F-test of overall significance: $0.00^{* *}$ & & & & & \\
\hline
\end{tabular}

* denotes $p<0.05$, **denotes $p<0.01$.

Table 1 (B) Results of Fixed Effect Model on the U.S. Apparel Industry

\begin{tabular}{lcrrrrrr}
\hline $\operatorname{Ln}\left(1-I P R_{i t}\right)$ & $\begin{array}{c}\text { Productivity } \\
\operatorname{Ln}\left(A_{i t}\right)\end{array}$ & $\begin{array}{c}\text { Employment } \\
\operatorname{Ln}\left(L_{i t}\right)\end{array}$ & $\begin{array}{l}\text { Wage } \\
\operatorname{Ln}\left(W_{i t}\right)\end{array}$ & $\begin{array}{c}\text { Market price } \\
\operatorname{Ln}\left(P_{i t}\right)\end{array}$ & $\begin{array}{c}\text { GDP } \\
\operatorname{Ln}\left(Y_{t}\right)\end{array}$ & $\begin{array}{c}\text { Quota } \\
\text { quota }\end{array}$ & $\begin{array}{c}\text { Time } \\
t\end{array}$ \\
\hline Apparel & 0.04 & -0.02 & -0.15 & $-0.50^{*}$ & -0.12 & -2.15 & 0.19 \\
$\quad$ industry & $(0.04)$ & $(0.02)$ & $(0.52)$ & $(0.22)$ & $(0.57)$ & $(1.92)$ & $(3.33)$ \\
Constant: 82.03 (66.5) & & & & & & \\
P-value for F-test of overall significance: $0.00^{* *}$ & & & & \\
\hline
\end{tabular}

* denotes $p<0.05$, **denotes $p<0.01$. 


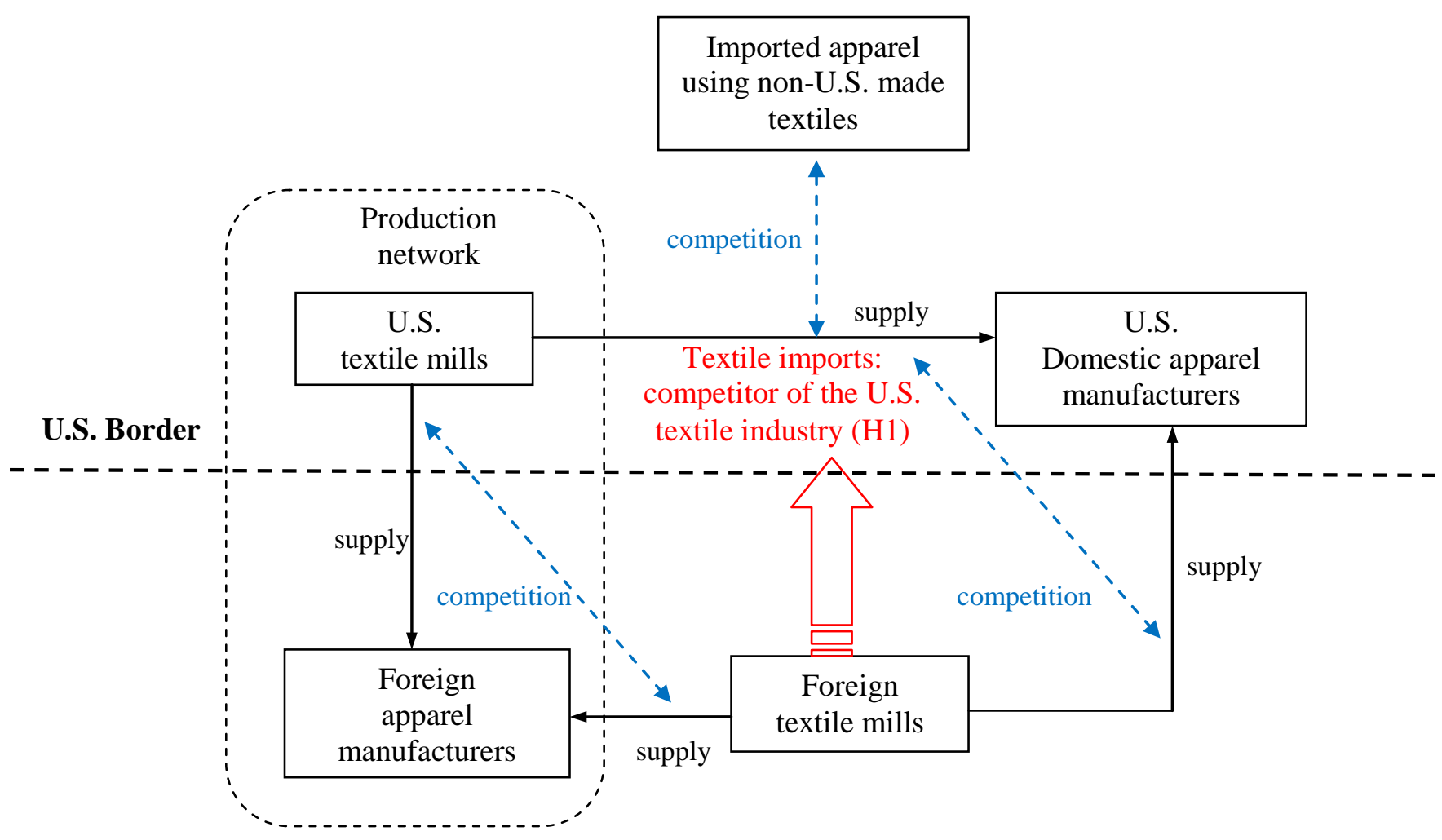

Figure 1 Conceptual Model of the Relationship Between Import Penetration and the Operation of the U.S. Textile Industry ${ }^{1}$

\footnotetext{
${ }^{1}$ Two other things need to be noted in Figure 1, although they will not be tested in this paper. First, the U.S. domestic textile industry is not only directly competing with textile imports, but also competes directly with imported apparel which uses non-U.S.-made textile products, although in an indirect way. With the quick rise of apparel imports since the 1990s, output of the U.S. apparel industry first started to decline and then followed up by the U.S. textile industry. This pattern suggested that a good proportion of prior U.S. domestic demand for textiles disappeared because of the shrinkage of U.S. domestic apparel production as the result of rising apparel imports. Second, the U.S. textile industry also competes with foreign-made textiles in third-country markets such as Mexico and Central-South American countries (Gereffi, 2002).
} 


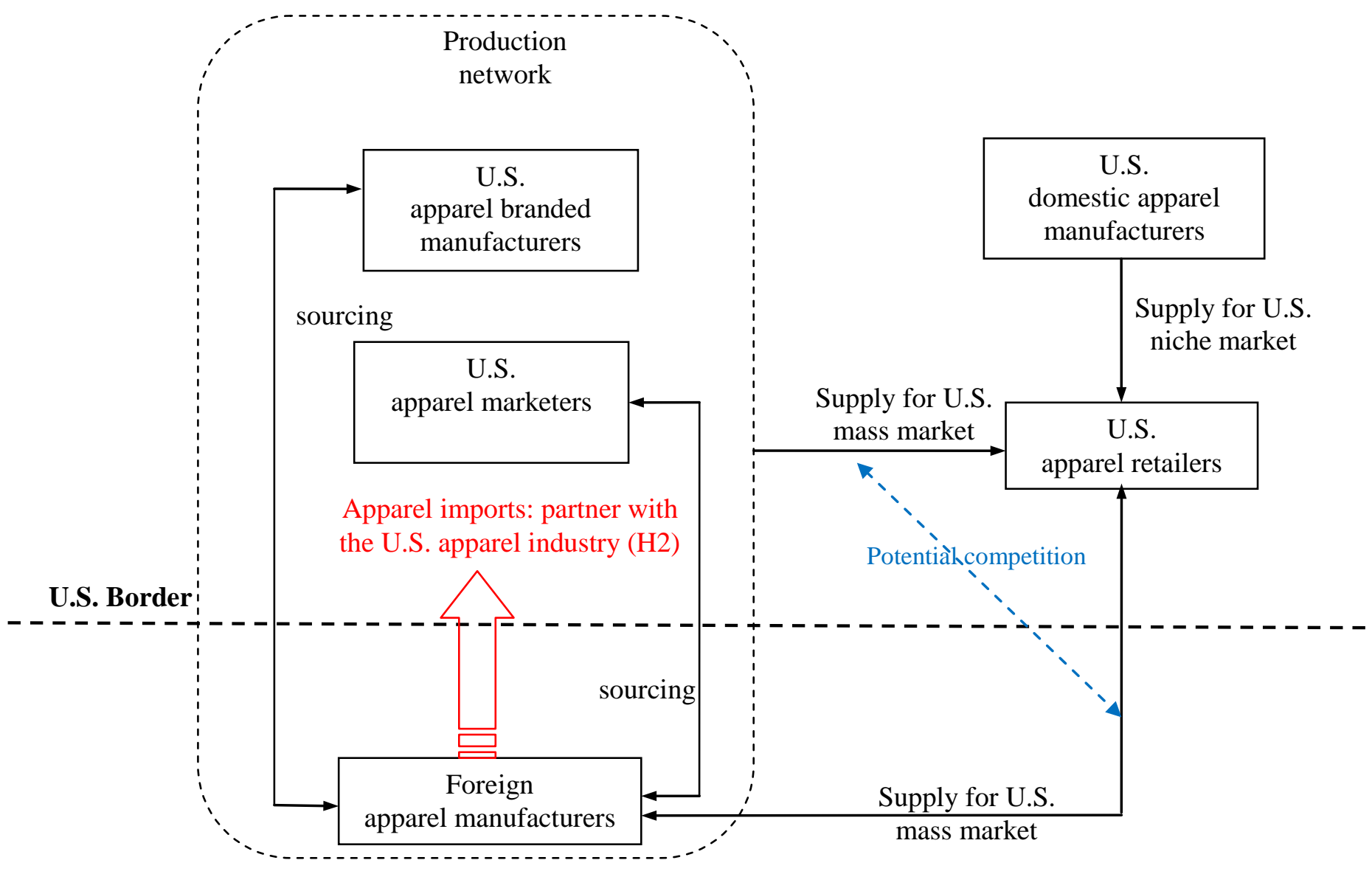

Figure 2 Conceptual model of the Relationship between Import Penetration and the Operation of the U.S. Apparel Industry 